Studies on the Glucose and Lipid Metabolism and Their Related Hormones in Hereditary Obese-hyperglycemic Mice

3. Effect of Some Hormones on Nonesterified Fatty Acid (NEFA) Release from Liver, Diaphragm and Epididymal Adipose Tissue

\title{
Toshiharu KAMIOKA
}

Department of Physiology, Wakayama Medical College (Director : Prof. Hiroshi Matsushita)

The effects of some hormones upon NEFA release from liver slice, diaphragm and epididymal adipose tissue were investigated. Each tissue of the Hereditary Obesehyperglycemic Mice (C57/6J-ob, OH) and New Zealand Obese Mice (NZO) were incubated with hormones in the medium of Krebs-Ringer Bicarbonate buffer containing $3 \%$ bovine albumin and 5\% Ediol (Emultion of 50\% coconut oil).

The results obtained are as follow:

1) Effects of epinephrine and norepinephrine on NEFA release from liver slice and diaphragm were similar to those of their control mice.

2) Epididymal adipose tissue from $\mathrm{OH}$ mice exhibited an impairment in its ability to release NEFA when incubated with epinephrine, norepinephrine and ACTH. The inhibitory action of insulin and glucose on NEFA release was also less marked in epididymal adipose tissue from $\mathrm{OH}$ mice than in their control mice. However, this abnormality was not found in tissue from NZO mice.

Decrease sensitivity to those hormones on NEFA release from $\mathrm{OH}$ mice in vitro may be one of the metabolic abnormalities in this type of hyperglycemic obesity.

(pp. 154 158) 


\title{
遺伝性肥満高血糖マウスによる糖, 脂質代謝と その関連ホルモンの研究
}

\author{
III. C57BL/6J-ob Mice 及び New Zealand Obese Mice \\ の脂肪酸動員に及ぼすホルモンの影響について
}

和歌山県立医科大学第二生理学教室（指導 松下 宏教授）

上岡利春

末梢組織，特に脂肪組織の非エステル型脂肪酸（NEFA）動員は絶食や寒冷に曝す事により著明に増加す $ろ^{\left.1)^{2}\right)}$.

然しながら，乙の研究報告の第 1 編 $^{3}$ 亿於て著者が報告した如く，肥満高血糖突然変異系マウス, C57BL/ $6 \mathrm{~J}-\mathrm{ob}(\mathrm{OH})$ の脂肪組織は対照マウスに比べて低い測定值を示した。 OHマウスの NEFA 動員の低下は肝 及び横隔膜に比べて脂肪組織に於てより早期に認められ，乙の系統動物の最も著明な代謝異常の一つである 事が示された。 OHマウスの脂肪組織のとの様な異常性は lipolytic enzyme の減少， lipolytic enzyme の 促進因子に対する感受性の低下， lipolytic enzyme の抑制因子の存在等種々の囚子が考えられるが，この報 告では lipolytic enzyme に対する種々の促進因子又は抑制因子の作用の異常性について検討した.

\section{実験方法及び材料}

\section{実験動物}

C57BL/6J-ob mice $(\mathrm{OH})$ 及び New Zealand Obese mice (NZO) を実験動物とし，前者の対照には同 腹正常マウスを，後者の対照には同月令の Swiss albino mice を用いた，又 OH マウスは生後 $3-6$ 力月 の個体を，NZO マウスは生後 5-7 カ月の個体を使用した.

\section{実験方法}

肝切片，横隔膜及び脂肪組織の調製法はすでに述べた方法3)によつた３％ Bovine albumine，5\% Ediol 含有の Krebs-Ringer bicarbonate 緩衡液（pH7.4）をインキュベーションメヂウムとし，てれに種 々の濃度の薬剤を添加して $37^{\circ} \mathrm{C} て ゙ 2$ 時間インキュベートした. インキュベーション前後のメヂウム中の NEFA 量 $(\mu \mathrm{Eq} / \mathrm{g} . \mathrm{L})$ 及びグリセロール量 $(\mu \mathrm{mole} / \mathrm{g})$ を测定した. NEFA 測定は Dole 法 $\left.{ }^{5}\right) に よ り$, 又 グリセロールは Korn 法出によつた。尚エピネフリン，ノルェピネフリン，ACTH，インスリン等の製剤は 市販品を供した。

\section{実 験 結 果}

副䅸丸脂肪組織による実験成績を Table 1, 2 及び 3 に示した. Table 1 及び 2 は OH マウスによるもの であり，Table 3 は NZO マウスのものである. Table 1 は NEFA の遊離量を示したものであるが，エピ ネフリン $10^{-2} \mathrm{mg} / \mathrm{cc}$ 添加による NEFA 動員の増加は対照マウスの $143 \%$ 対し OHマウスでは $30.9 \%$ 過 ぎず増加率は甚だ少ない，ノルエピネフリン $10^{-2} \mathrm{mg} / \mathrm{cc}$ 添加による NEFA 動員の増加も対照マウス $116 \%$ に対しOHマウスは58\%でエピネフリンと同様 OHマウスの増加率は非常に低い. 同様に ACTH0.1U/cc 添 加の際もかなり低い NEFA 動員の増加率が示された. NEFA 動員抑制因子であるインスリン0.4U/cc添加

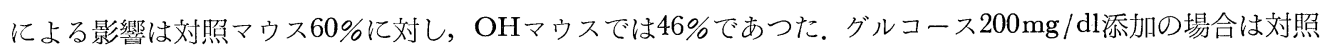
マウス $52 \%, \mathrm{OH}$ ウス $33 \%$ NEFA 動員抑制率を示した. 
Table 1. Effect of epinephrine, norepinephrine, ACTH, insulin and glucose on NEFA release from epididymal adipose tissue of $\mathrm{OH}$ and their control mice

Values are expressed as $\mu \mathrm{Eq}$ per gram per 1000cc. of NEFA release in 120 minutes Number in parenthese indictes number of experiments The mice employed were ranged in 4 to 6 months of age

\begin{tabular}{|c|c|c|c|c|c|c|c|c|c|c|}
\hline \multirow{2}{*}{ Animals } & \multicolumn{2}{|c|}{ Epinephrine } & \multicolumn{2}{|c|}{ Norepinephrine } & \multicolumn{2}{|c|}{ ACTH } & \multicolumn{2}{|c|}{ Insulin } & \multicolumn{2}{|c|}{ Glucose } \\
\hline & None & $\begin{array}{c}10^{-2} \\
\mathrm{mg} / \mathrm{cc}\end{array}$ & None & $10^{-2} \mathrm{mg} / \mathrm{cc}$ & None & $0.1 \mathrm{U} / \mathrm{cc}$ & None & $0.4 \mathrm{U} / \mathrm{cc}$ & None & $020 \mathrm{mg} \%$ \\
\hline $\begin{array}{l}\text { Control } \\
\text { mice }\end{array}$ & $\begin{array}{c}466 \pm 62 \\
(7)\end{array}$ & $\mid \begin{array}{c}1131 \pm 22 \\
(7)\end{array}$ & $\begin{array}{c}482 \pm 57 \\
(7)\end{array}$ & $\begin{array}{c}1051 \pm 152 \\
(7)\end{array}$ & $\begin{array}{c}536 \pm 56 \\
(8)\end{array}$ & $\begin{array}{c}665 \pm 76 \\
(8)\end{array}$ & $\mid \begin{array}{c}440 \pm 126 \\
(8)\end{array}$ & $\begin{array}{c}176 \pm 43 \\
(8)\end{array}$ & $\begin{array}{c}494 \pm 60 \\
(8)\end{array}$ & $\begin{array}{c}237 \pm 44 \\
(8)\end{array}$ \\
\hline $\mathrm{OH}$ mice & $\begin{array}{c}321 \pm 46 \\
(7)\end{array}$ & $\begin{array}{c}440 \pm 52 \\
(7)\end{array}$ & $\begin{array}{c}301 \pm 39 \\
(7)\end{array}$ & $\begin{array}{c}477 \pm 54 \\
(6)\end{array}$ & $\begin{array}{c}313 \pm 53 \\
(7)\end{array}$ & $\begin{array}{c}334 \pm 45 \\
(8)\end{array}$ & $\mid \begin{array}{c}324 \pm 49 \\
(7)\end{array}$ & $\begin{array}{c}176 \pm 33 \\
(8)\end{array}$ & $\begin{array}{c}328 \pm 18 \\
(8)\end{array}$ & $\begin{array}{c}220 \pm 38 \\
(6)\end{array}$ \\
\hline
\end{tabular}

Table 2. Effect of epinephrine, norepinephrine, ACTH and insulin on glycerol release from epididymal adipose tissue of $\mathrm{OH}$ and their control mice.

Values are expressed as $\mu$ mol per gram per 2 hours of glycerol release.

Number in parentheses indicates number of experiment.

The mice employed in 3 to 6 months of age.

\begin{tabular}{c|c|c|c|c|c|c|c|c}
\hline \multirow{2}{*}{ Animals } & \multicolumn{2}{|c|}{ Epinephrine } & \multicolumn{2}{c|}{ Norepinephrine } & \multicolumn{2}{|c|}{ ACTH } & \multicolumn{2}{c}{ Insulin } \\
\cline { 2 - 8 } & None & $10^{-2} \mathrm{mg} / \mathrm{cc}$ & None & $10^{-2} \mathrm{mg} / \mathrm{cc}$ & None & $0.1 \mathrm{U} / \mathrm{cc}$ & None & $0.4 \mathrm{U} / \mathrm{cc}$ \\
\hline \multirow{2}{*}{$\begin{array}{c}\text { Control } \\
\text { mice }\end{array}$} & $3.50 \pm 0.4$ & $6.02 \pm 0.8$ & $3.50 \pm 0.4$ & $5.44 \pm 0.7$ & $3.50 \pm 0.4$ & $3.91 \pm 0.5$ & $4.25 \pm 0.6$ & $0.20 \pm 0.3$ \\
& $(8)$ & $(7)$ & $(8)$ & $(8)$ & $(9)$ & $(9)$ & $(6)$ & $(8)$ \\
\hline \multirow{2}{*}{ OH mice } & $2.51 \pm 0.4$ & $3.91 \pm 0.5$ & $2.51 \pm 0.5$ & $3.45 \pm 5$ & $2.5 \pm 0.2$ & $3.00 \pm 0.4$ & $2.92 \pm 0.3$ & $1.61 \pm 0.3$ \\
& $(7)$ & $(7)$ & $(6)$ & $(6)$ & $(7)$ & $(6)$ & $(8)$ & $(6)$ \\
\hline
\end{tabular}

Table 3. Effect of epinephrine, norepinephrine, insulin and glucose on NEFA release from epididymal adipose tissue of NZO mice and their control mice.

Values are expressed as $\mu \mathrm{Eq}$ per gram per 1000cc. of NEFA release in 120 minutes.

Number in parentheses indicates number of experiment.

The mice employed were ranged in 5 to 7 months of age

\begin{tabular}{c|c|c|c|c|c|c|c|c}
\hline \multirow{2}{*}{ Animals } & \multicolumn{2}{|c|}{ Epinephrine } & \multicolumn{2}{c|}{ Norepinephrine } & \multicolumn{2}{|c|}{ Insulin } & \multicolumn{2}{c}{ Glucose } \\
\cline { 2 - 9 } & None & $10^{-2} \mathrm{mg} / \mathrm{cc}$ & None & $10^{-2} \mathrm{mg} / \mathrm{cc}$ & None & $0.4 \mathrm{U} / \mathrm{cc}$. & None & $200 \mathrm{mg} \%$ \\
\hline \multirow{2}{*}{$\begin{array}{c}\text { Control } \\
\text { mice }\end{array}$} & \begin{tabular}{c}
$477 \pm 64$ \\
\cline { 6 - 9 }
\end{tabular} & $1245 \pm 180$ & $550 \pm 57$ & $1300 \pm 180$ & $510 \pm 52$ & $201 \pm 30$ & $540 \pm 66$ & $279 \pm 44$ \\
\hline \multirow{2}{*}{ NZO mice } & $450 \pm 57$ & $1011 \pm 170$ & $499 \pm 57$ & $1092 \pm 150$ & $477 \pm 56$ & $250 \pm 32$ & $470 \pm 52$ & $262 \pm 36$ \\
& $(9)$ & $(9)$ & $(9)$ & $(9)$ & $(8)$ & $(8)$ & $(9)$ & $(8)$ \\
\hline
\end{tabular}

Table 2 は上の成績を確認する為にグリセロール遊出を全く同様な系による方式で測定した結果である。乙 の表の成績は Table 1 の NEF 動員のそれと全く同一の傾向を示した. OH マウスの副睪丸脂肪組織に於て 
はかくの如く著明な脂肪分解促進及び抑制ホルモン等に対する感受性の低下がみられたが，肝及び横隔膜組 織ではこの様な傾向は認められなかつた。

Table 3 の NZO マウスの脂肪組織の NEFA 動員はエピネフリン,ノルエピネフリン及びインスリンに良 く反応し，その感受性は対照マウスとの間に差異を認めなかつた。NZOマウスの肝及び横隔膜組織でも $\mathrm{OH}$ マウスと同様対照マウスとの間に差異を全く認めなかつた。

脂肪代謝に於けるグルコースの存在意義は非常に重要である。にてでメヂウムにグルコース $200 \mathrm{mg} / \mathrm{dl}$ を 共存させてエピネフリン，ノルエピネフリン, ACTH 及びインスリンの影響を観察し，その成績を Table 4

Table 4. Effect of some hormones on NEFA release from epididymal adipose tissue incubated with glucose.

Values are expressed as $\mu \mathrm{Eq}$ per gram per 1000cc. of NEFA release. Number in parentheses indicates number of experiment. The mice employed were 4 to 6 months of age. Medium cotained $200 \mathrm{mg} \%$ of glucose.

\begin{tabular}{c|c|c|c|c|c|c|c|c}
\hline \multirow{2}{*}{ Animals } & \multicolumn{2}{|c|}{ Epinephrine } & \multicolumn{2}{|c|}{ Norepinephrine } & \multicolumn{2}{c|}{ AGTH } & \multicolumn{2}{|c}{ Insulin } \\
\cline { 2 - 9 } & None & $10^{-2} \mathrm{mg} / \mathrm{cc}$. & None & $10^{-2} \mathrm{mg} / \mathrm{cc}$. & None & $0.1 \mathrm{U} / \mathrm{cc}$. & None & $0.4 \mathrm{U} / \mathrm{cc}$. \\
\hline \multirow{2}{*}{$\begin{array}{c}\text { Control } \\
\text { mice }\end{array}$} & $194 \pm 49$ & $592 \pm 96$ & $140 \pm 39$ & $410 \pm 65$ & $125 \pm 35$ & $195 \pm 33$ & $195 \pm 50$ & $31 \pm 13$ \\
\hline \multirow{2}{*}{ OH mice } & $(5)$ & $(5)$ & $(4)$ & $(4)$ & $(5)$ & $(5)$ & $(6)$ & $(6)$ \\
\hline
\end{tabular}

そ示した。 Table 1 亿示した如くOHマウスの NEFA 動員は対照マウスに比べて通常著じるしく低い值を示 すが，グルコース $200 \mathrm{mg} / \mathrm{dl}$ の存在下では，乙れが殆んど同程度になつた。エピネフリン，ノルェピネフリ ン及び AGTH の添加は対照マウスの NEFA 動員を著明に増加せしめたが，OHマウスのそれは僅少であ つた。 又インスリン添加も対照マウスに対しては著明な NEFA 動員抑制を示したのに反し，OHマウスに 於ける抑制率は対照マウスに比べ極めて僅かであつた。即ちOHマウスの NEFA 動員はグルコース存在下 でもこれらのホルモンに対して低い感受性を示した。

Table 5 は Table 1, Table 2 及び Table 3 の結果を併せて, 各種ホルモンの NEFA 動員促進率及び抑 制率(一)を\%で示したものである。乙れより明らかな如く,グルコースの存在下ではインスリンの抑制率は

Table 5. Effect of some hormones and glucose on NEFA release from epididymal adipose tissue of $\mathrm{OH}$ and their control mice

\begin{tabular}{c|c|c|c|c}
\hline \multirow{2}{*}{ Hormones added } & \multicolumn{2}{|c|}{ No glucose } & \multicolumn{2}{|c}{ Glucose } \\
\cline { 2 - 5 } & Control mice & OH mice & Control mice & OH mie \\
\hline None & $0 \%$ & $0 \%$ & $-52.2 \%$ & $-39.1 \%$ \\
\hline Insulin $(0.4 \mathrm{U} / \mathrm{cc})$ & $\begin{array}{c}-64.5 \\
(-59)\end{array}$ & $\begin{array}{c}-51.5 \\
(-38)\end{array}$ & -93.8 & -71.6 \\
\hline Epinephrine $\left(10^{-2} \mathrm{mg} / \mathrm{cc}\right)$ & $\begin{array}{c}76.6 \\
(107)\end{array}$ & $\begin{array}{c}8.6 \\
(70)\end{array}$ & 19.6 & -25.4 \\
\hline Norepinephrine $\left(10^{-2} \mathrm{mg} / \mathrm{cc}\right)$ & $\begin{array}{c}110.7 \\
(72)\end{array}$ & $\begin{array}{c}3.7 \\
(35)\end{array}$ & -17.2 & -44.7 \\
\hline ACTH $(0.1 \mathrm{U} / \mathrm{cc})$ & $\begin{array}{c}34.3 \\
(43)\end{array}$ & $\begin{array}{c}7.7 \\
(11)\end{array}$ & -60.6 & -59.4 \\
\hline
\end{tabular}


Table 6. Effect of epinephrine and insulin on NEFA release from epididymal adipose tissue of $\mathrm{OH}$ mice and their control mice.

Values are expressed as $\mu \mathrm{Eq}$ per gram per $1000 \mathrm{cc}$. of NEFA release. The mice employed are about 5 months of age.

\begin{tabular}{c|c|c|c|c}
\hline Animals & $\begin{array}{c}\text { No. of } \\
\text { Animals }\end{array}$ & None & $\begin{array}{c}\text { Epinephrine (10mg/cc.) } \\
\text { and } \\
\text { Insulin }\end{array}$ \\
\hline Control mice & 8 & $\begin{array}{c}582 \pm 66 / \mathrm{cc} .) \\
(8)\end{array}$ & $\begin{array}{c}1001 \pm 151 \\
(8)\end{array}$ \\
\hline OH mice & 6 & $\begin{array}{c}400 \pm 42 \\
(8)\end{array}$ & $\begin{array}{c}582 \pm 62 \\
(7)\end{array}$ \\
\hline
\end{tabular}

が確認された。
極めて增加し, 逆に ACTH の NEFA 動員促進作用は殆んど認められなかつ た. 然しエピネフリンのみは依然とし てその作用が㴓められた。，ルエピネ フリンの NEFA 動員促進作用はグル コースによつて減少が認められた。

最後に NEFA 動員に対するインス リン，エピネフリンの併用効果につい て検傠した。実験結果は Table 6 亿示 す如く，エピネフリンとインスリンの 其存は刘照マウス及びOH マウスに対 し NEFA 動員の促進的効果を示した。 然しOH マウスは対照マウスに比べて その促進率は低く, 感受性に乏しい事

\section{考察}

この報告の第 1 編に示した如く, OHマウスの脂肪組織の NEFA 動員は摄食㭙対照マウスより高い值を 示すのに反し, 絶食時に於ける NEFA 動員促進率は対照マウスに比べて極めて低い. この様な現象はOH マウスの脂肪組織に於ける脂肪酸分解醉素が所謂その促進ホルモン67) に対しより低い感受性を示す事によ るものと想像される。

この仮定に基づき，著者は in vitro の NEFA 動員に及ぼすエピネフリン，ノルェピネフリン及び AGTH の所謂脂肪分解促進ホルモンの影響を実験した。 その結果推察通りにOHマウスの副睪丸脂肪組織の NEFA 動員はこれらのホルモンに対する感受性が対照マウスに比べて異常に低い事が確認された。乙れらの結果は Mayer ら $^{899}$ の報告と一致するものである，然し肝及び横隔膜組織ではての様な成績はみられず，又 NZOマ ウスではいずれの組織でも対照マウスとの間に差異を見出し得なかつた。 NEFA動員抑制剤としてインスリ ン及びグルコースの影響も同時に検討したが結果は NEFA 動員促進ホルモンと全く同様に, OHマウスの 副殬丸脂肪組織に於てのみ対照マウスとの差異, 即ちインスリン及びグルコースの抑制作用の感受性の低下 を認めた。 この様な脂肪代謝の異常性はOHマウスの脂肪組織に於てのみ見られ，OH マウスと同様肥満高 血糖症状を示すNZOマウスでとの様な異常が全く認められなかつた．乙の様な成績はOHマウスの脂肪組織 そ於ける異常性は肥満高血糖の一次的因子ではなく, むしろOHマウスの脂肪組織で早期より見られる蓄積 脂肪の異常増加に基づく脂肪組織細胞の機能低下による二次的現像である事を示すものと考えられる.

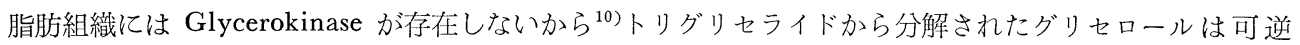
的に再利用され得ない，従つてトリグリセライドの合成に必要なグリセロホスフェートはグルコースの投与 に待たねばならない. この事はTable 5 に於いて単にグルコースのみの存在で NEFA の動員が対照マウスで -52.2\%，OHマウスでー39.1\%の抑制が見られた事から明らかな如く，グルコースは動員された NEFAの 再エステル化に役立つものと考えられる。Table 5 は又各種ホルモンの影響をグルコースの存在の有無につ いて比較したものである.既に述べた如くグルコースの有無にかかわらず用いたホルモンに関しては,いずれ も $\mathrm{OH}$ マウスは対照マウスに比べて感受性の低い事が確認された。インスリン作用はグルコースの存在によ り著明に増強されるのがみられ，インスリンの NEFA の再エステル化作用をグルコースに由来するグリセ ロホスフェートが助長している事を示している. ACTH 作用及びOHマウスに於けるノルエピネフリン作 用はグルコースの添加により抑制される如き成績を得た。然しエピネフリン作用は若干の抑制はみられたが 尚可成りの程度に残存しており，Buckle ${ }^{11)}$ のラットの脂肪組織による実験成績と全く一致している，Jurgas 
ら ${ }^{12}$ は土ピネフリンによつて脂肪の分解が促進されて生産された NEFA はグルコースがメデウムに添加さ れずともインスリンによつて減少する事を報告している. Table 6 の成績はてれを追試すると同時にOHマウ スについても平行して央験した成績である。対照正常マウスに於いてエピネフリン $10^{-2} \mathrm{mg} / \mathrm{cc}$ 単独を用いた Table 1 の $143 \%$ の增加に比べて，エピネフリン $10^{-2} \mathrm{mg} / \mathrm{cc} ，$ インスリン $0.4 \mathrm{U} / \mathrm{cc}$ 渌加の Table 6 ではその NEFA 動員促進率は73\%であり, 明らかにエピネフリンによつて動員された NEFAがインスリンにより再 エステル化されている事がうかがえる。但しOHマウスでは Table 1 に於て $30.9 \%$ ，Table 6 では45\%と大 差なく正常マウス及びラッテと著るしく異なり，乙の点に於ても OHマウスの脂質代謝のホルモン感受性の 異常性が強調せられる。

\section{結語}

NZO マウス及びOHマウスの肝, 横隔膜及び脂肪組織の NEFA 動員に及ぼす NEFA 動員促進因子及び 抑制因子の影響を in vitro で観察し次の様な結果を得た。

1) NZOマウスの肝，横隔膜及び脂肪組織の NEFA 動員に対するエピネフリン，ノルエピネフリンの影 響は対照マウスと同様であり，異常性は認めなかつた。脂肪組織の NEFA 動員に及ぼすグルコース及びイ ンスリンの影響も正常であり異常性はみられなかつた。

2) OHマウスの肝及び横隔膜の NEFA 動員に対するエピネフリン，ノルエピネフリンの影響は正常で あつた。

3） OHマウスの副睪丸脂肪組織の NEFA 動員に対するエピネフリン，ノルエピネフリン及び ACTH の影響は著明に低下していた。 又インスリン及びグルコースに対する感受性の低下も認められた。

扔わりに御指導を賜わつた松下宏教授に深謝すると共に種々の御援助を頂いた教室員諸氏, 殊に技術的な 協力を顶いた河端㤵子氏に厚く御礼申し上げます。

尚本研究費の一部は略和 37 年度文部省和学研究費 (710221) 飞よつた。本本論文の要旨は第41回日本生理 学総会及び第37回日本内分䎵学会総会に於いて発表した。

\section{文献}

1) SELlers, E.A., J.W. SCOTT \& N. THOMAS : Am. J. Physiol., $177: 372$, (1954). MARTHA, VAUGHAN : J. Biol. Chem., $237:$ 3354, (1962).

3) 上岡利春 : 日本内分泌学雑誌. 4) EDWARD D. KORN : J. Biol. Chem., $251: 1$, (1955).

5) DOL, V.P. : J. Clin. Invest., 35 : 150, (1956). $\quad 6)$ RIZAK, M.A. : J. Biol. Chem., $236: 657$, (1961).

7) HOLLENBERG, C.H., RABEN, M.S., \& ASTWOOD, E.B. : Endocrinol., 68 : 589, (1961). 8) MOROBALL, N.B., \& ENGEL, F.L. : J. Lipid Res. : 1, 339, (1960). 9) LEBOEUF, B., LOCHAYA, S., LEBOEUf, N., WOOD, JUN., F.G., MAYER, J., \& GAHILL. JUN., G.F. : Am. J. Physiol., 201 : 19, (1961). 10) WIELAND, O., \& SUYTER, M. : Biochem. Z., $329: 320$, (1957). BUCKLE, R.M., RUBINSTEIN, D., MOGARY, E.E., \& BEK, J.G. : Endocrinol., 69 : 1009, (1961). 12) JUNGAS, R.L., \& BALL E.G. : Biochem., 2 : 383, (1963). 